\title{
Ultrasound Examination of Gynecomastia Case in Male Patient: Case Report
}

\author{
Puji Supriyono ${ }^{1}$, Gando Sari ${ }^{1}$, Nursama Heru Apriantoro ${ }^{1}$, Win Priantoro ${ }^{1}, \operatorname{Samsun}^{1}$, Mayarani ${ }^{1}$, Eka Putra Syarif $^{1}$, \\ Sri Rebekka ${ }^{2}$, Sri Kartini ${ }^{3}$ \& Humala Prika Aditama ${ }^{4}$ \\ ${ }^{1}$ Department of Radiodiagnostic and Radiotherapy, Politeknik Kesehatan Kemenkes Jakarta II, Jakarta, Indonesia \\ ${ }^{2}$ Radiology Unit, District General Hospital of Cengkareng, Jakarta Barat, Jakarta, Indonesia \\ ${ }^{3}$ Radiology Unit, Dr Mintohardjo Navy Hospital Jakarta, Indonesia \\ ${ }^{4}$ General Practitioner, Puri Indah, Pondok Indah Hospital, Jakarta, Indonesia \\ Correspondence: Puji Supriono, Department of Radiodiagnostic and Radiotherapy, Politeknik Kesehatan \\ Kemenkes Jakarta II, Hang Jebat III/F-3, Jakarta 12120, Indonesia. Tel/Fax: 62-21-720-6239. E-mail: \\ puji_supriyono@yahoo.com
}

Received: January 21, 2018 Accepted: February14, 2018 Online Published: February 26, 2018

doi:10.5539/gjhs.v10n4p7 URL: https://doi.org/10.5539/gjhs.v10n4p7

\begin{abstract}
Gynecomastia is hypertrophy abnormality of male's breast gland soft tissue. In that case, the mammography is difficult to show the malignant masses. The ultrasonography is often useful and really important examination to confirm the diagnosis by showing retroareolar hypoechoic mass and or elevation of hyperechoic on parenchyma gland. Gynecomastia is very rare cases in older man. This case report shows 67 years old patient on compos mentis state, who has left breast enlargement.
\end{abstract}

Keywords: gynecomastia, male's breast, benign, ultrasonography

\section{Introduction}

Gynecomastia is defined as an enlargement of the male breast. It is often benign and can be the source of significant embarrassment and psychological distress (Lemaine, 2013). It is an abnormal and excessive growth of male's breast tissue, commonly occurs in adults and middle age groups in general as a result of medications, nutritional supplements, and anabolic steroid consumption, usually athletes and bodybuilders (Stavros, 2004). In some cases, there were due to physiological, pathological and pharmacological factors (Oates, 2004). Physiologically, gynecomastia is caused by an imbalance between free estrogen and free androgen actions in the breast tissue. (Mathur \& Braunstein, 1997; Braunstein, 2007). It can occur in neonates, at puberty, and with obesity and aging. (Niewoehner \& Schorer, 2008; Johnson \& Murad, 2009). The basic mechanism of gynaecomastia caused by lowering of androgen production, elevation of estrogen production and elevation of estrogen precursor availability for estradiol conversion, therefore there are changes in estrogen and androgen ratio. Transition time from puberty to post-puberty is followed by elevation of testosterone by 30 times and estrogen by 3 times.

The main causes of gynecomastia were reported by (Cooper et al., 1994; Appelbaum et al., 1999; Charlot et al., 2013). That is Physiological (senescence, puberty), Endocrine (Klinefelter syndrome, hypogonadism, hypothyroidism), systemic disease (cirrhosis, chronic renal failure), tumors (testicular tumors, adrenal carcinoma, pituitary adenoma, hepatocellular carcinoma), Toxicity Medication (alcohol, cannabis, digoxin, cimetidine, thiazide diuretics, omeprazole, tricyclic antidepressants, spironolactone, diazepam, anabolic-androgen steroids, exogenous oestrogens), and idiopathic.

The primary modality of mammography is usually to diagnosis and classification of the breast (Chen \& Slanetz, 2014). However. it is not necessary to confirm gynecomastia through a mammogram (Tan et al., 2016). Furthermore, ultrasonography technique is appropriate to diagnose gynecomastia case to produce visualization image of breast tissue. (Berg \& Yang, 2014)

\section{Case Report}

67years old male patient was referred from surgeon's outpatient clinic to Radiology Unit for ultrasound examination of the breast. The physical feature of left breast is bigger than right breast, not symmetrical and 
uncomfortable feeling, slight pressure pain, no fever, no history of trauma, no history of similar illness in the family, no significant weight loss. The patient has suffered this condition since one year ago. Body Mass Index of 31.22 , the body temperature of $37^{\circ} \mathrm{C}$, heart rate of $64 \mathrm{bpm}$, Blood pressure of $125 \mathrm{per} 80 \mathrm{mmHg}$. On the previous examination, Thorax examination, laboratory routine, showed that there are no abnormalities in the chest.

The Ultrasound technique to show breast tissue until surface layer, cutis, and subcutis. Ultrasound machine used on the right hand was Phillips EPIQ 5G, which was calibrated until November 2019, A linear matrix probe transducer type L12-3 was used from Phillips with the frequency of $7 \mathrm{MHz}$ to $12 \mathrm{MHz}$, it was intended to visualize superficial mammary tissue, cutis, and subcutis layer.

Patient examined on supine position or abnormal part is located higher and hands on the same side above the head. Scanning technique on breast examination is different with common examination, the scanning was done with transversal and longitudinal projection on breast, on both breast, one by one, scanning was started from right axilla region to the left axilla region, next right breast on transversal projection by moving the transducer away from nipple on 12 o'clock, 3 o'clock, 6 o'clock, and 9 o'clock moved circularly with nipple as the axis, and then continue to left breast with measurement of hypoechoic lesion. (Berg \& Yang, 2014). The Image ultrasound of breast examination was an interpretation based on BI-RADS (Breast Imaging Reporting and Data System Standard) guidelines as shown Table 1.

Table 1. Classification of Ultrasoundbreast examination based on BI-RADS (ACR, 2014)

\begin{tabular}{ll}
\hline BI-RAD* Catagory & Reporting \\
\hline 0 & Need additional information. And/or prior mammogram for comparison \\
1 & Negative \\
2 & Benign Finding \\
3 & Probably benign finding. Short interval follow up suggested \\
4 & Suspicious abnormality-biopsy should be considered \\
5 & Highly suggestive of malignancy-Appropriate action should be taken \\
6 & Known biopsy-proven malignancy appropriate action should be taken \\
\hline
\end{tabular}

*Breast Imaging Reporting and Data System.

\section{Results and Discussion}

For gynecomastia cases in male patients, a mammography is not necessary for confirming a diagnosis. However, ultrasound examination is the most common and important to diagnosis of true gynecomastia, which has a specific presentation for detecting nodular diseases or malignant lesions (Muñoz et al., 2010; Draghi et al., 2011; Foo et al., 2017). In fact, more than of $95 \%$ of the male breast lesions were benign, as other authors reported (Chen et al., 2006; Muñoz et al., 2010). For optimal results of gynecomastia cases, it needs cooperation from the patient to be in supine position. To describe mammary soft tissue, therefore visualizing soft tissue of cutis, subcutis, fibro-glandular and muscular tissue with a transversal and longitudinal view, it should be done in transversal and longitudinal scanning. Scanning starts from right axilla region and then left axilla region, its purpose is to look for lesions in the axilla region so as to visualize cuticle tissue, subcutis, and muscle and lymph node lesions as an indicator of spread through lymph nodes (Rasad \& Ekayuda, 2005). To look for a benign lesion in gynecomastia cases around the breast, it was done on the transversal projection by moving the transducer away from nipple as clock direction on 12 o'clock, 3 o'clock, 6 o'clock and 9 o'clock. Scanning results of left breast in gynecomastia cases have been shown in Figure 1, and Figure 2 the scanning result appears bordered inhomogenous lesion in the left axilla. A result of left breast with Doppler Ultrasound Scanning has been seen in Figure 3. 


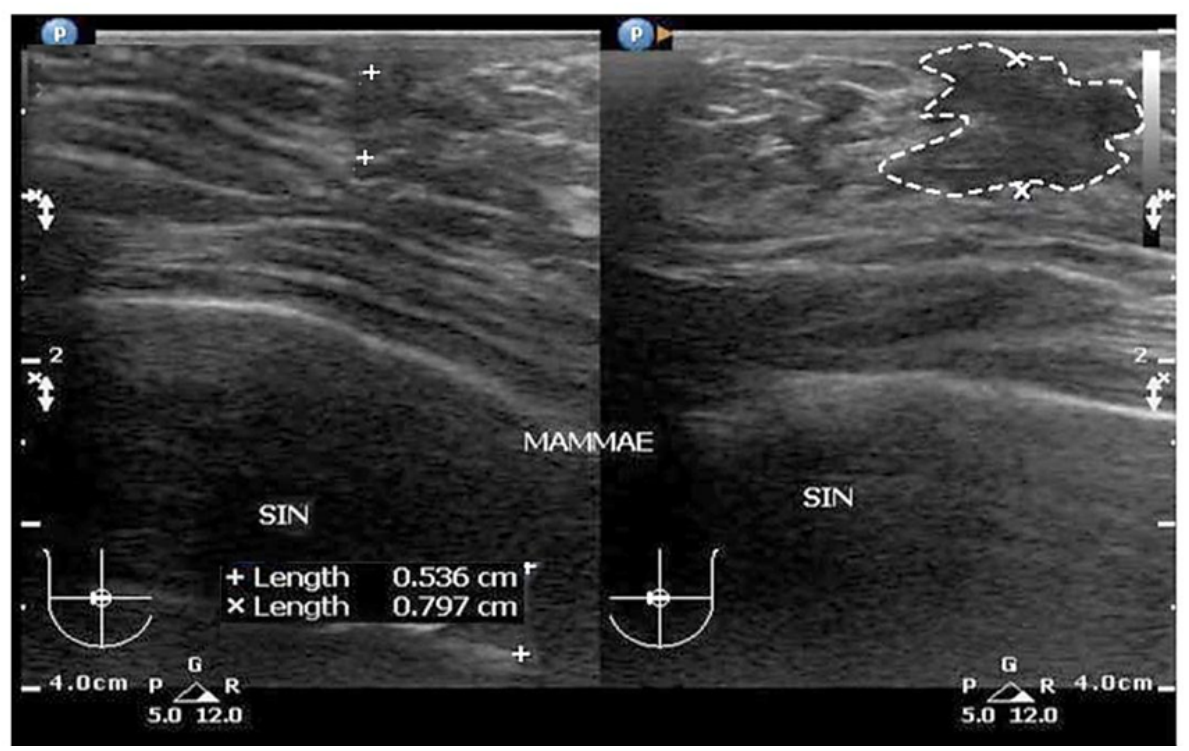

Figure1. Ultrasound image of Left Breast Scanning: It shown irregular edge hypoechoic lesions in left breast retroareola

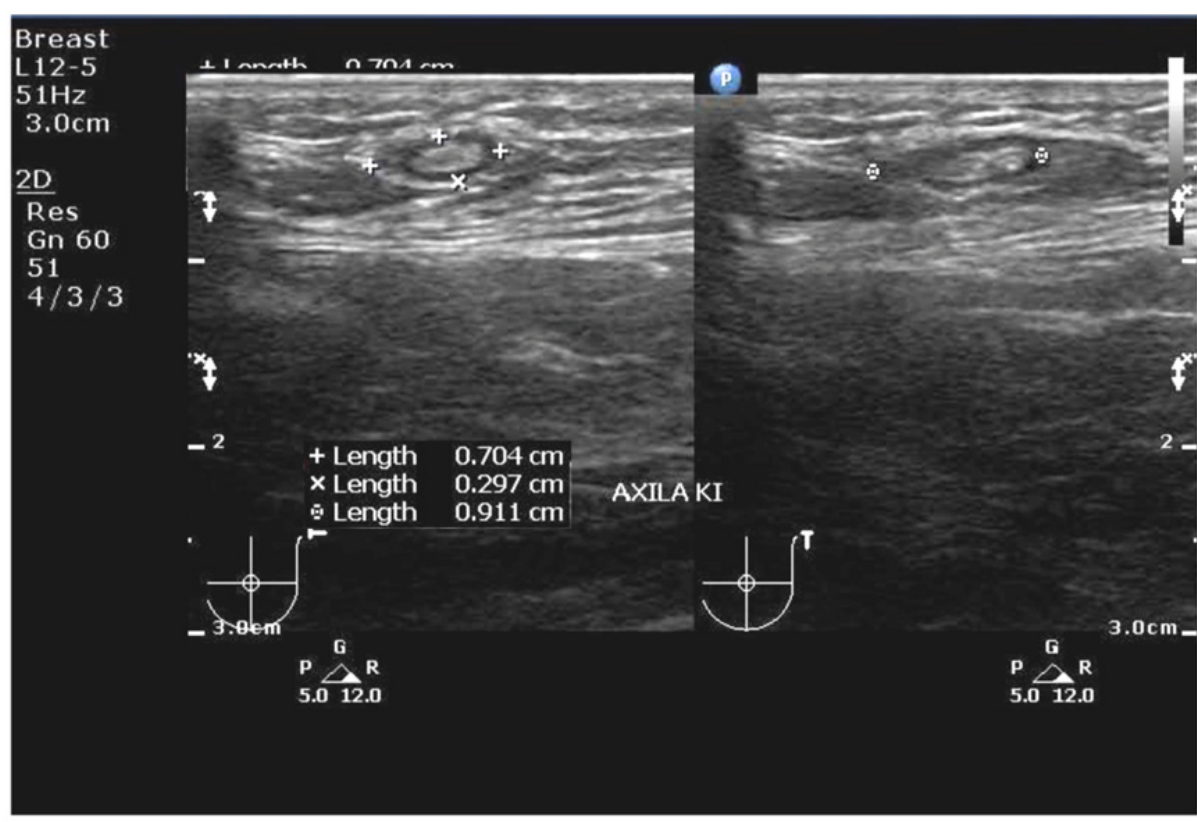

Figure 2. Ultrasound image of left axilla scanning: it shows irregular edge hypoechoic lesions in left axilla (lymphnode) 


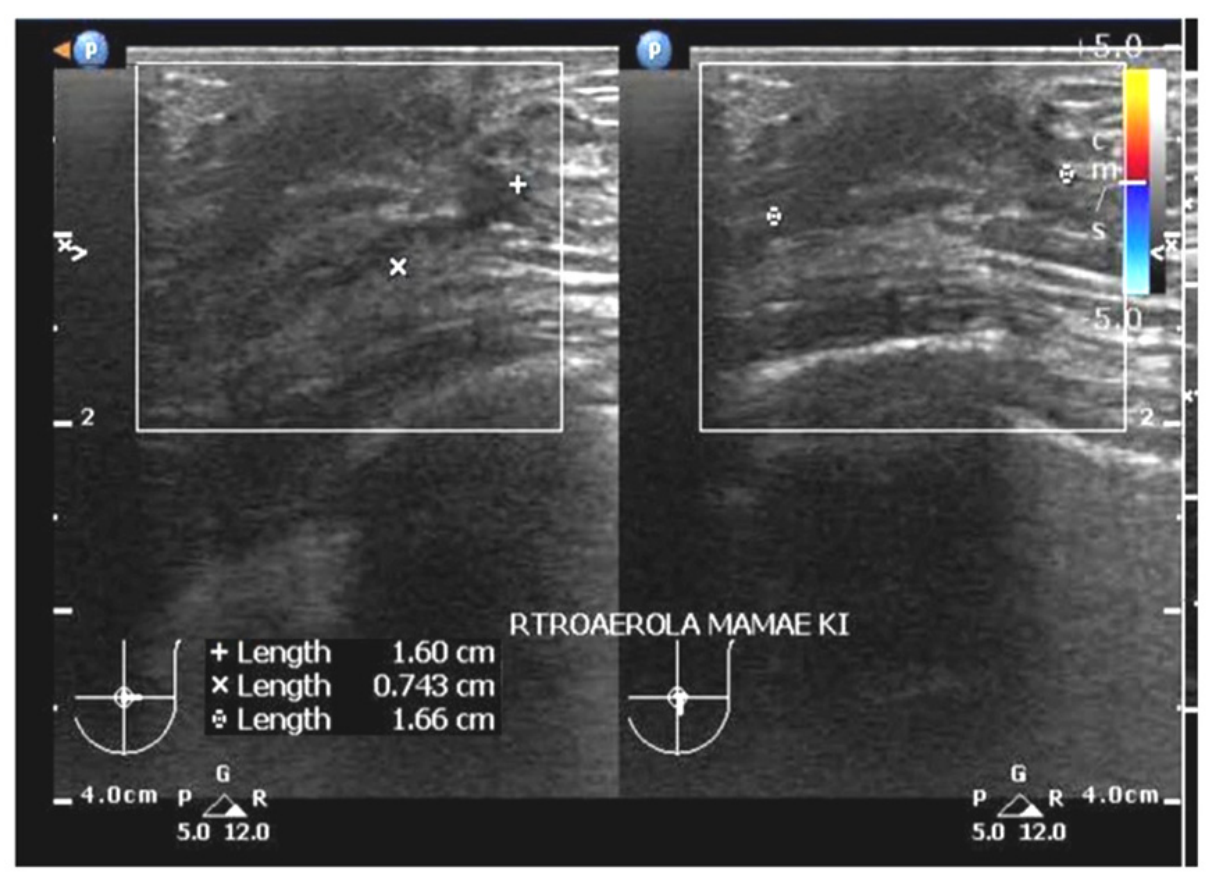

Figure 3. Result of left breast with Doppler Ultrasound Scanning: It inhomogeneous lesions are firmly defined in left axilla region. There is no blood vessels in lession area

For ultrasound evaluation in gynecomastia case on the left breast. Figure 1 shows cutis and subcutis are not thickening, this case demonstrates that there is hypoechoic lesion with an irregular edge at retro areola breast with the size of $0.536 \times 0.797 \mathrm{~cm}^{2}$. In Figure 2, the result of left axilla scanning of gynecomastia case, it shows irregular edge hypoechoic lesions in left axilla (lymph node) with the size of $0.704 \times 0.297 \times 0.911 \mathrm{~cm}^{3}$. The result of left breast with Doppler ultrasound scanning as shown in Figure 3, it appears inhomogeneous lesions with no vascular flow in the lesion, it's signed benign mass at retro areola left breast with the size of $1.60 \times 0.743 \times 1.66 \mathrm{~cm}^{3}$. Based on the evaluation of the ultrasound scanning images and physical examination of a patient, it was found a benign lesion classified as BI-RAD 4 category, that means biopsy technique should be used as the highest standard (gold standard) in the next procedure, it was obtain to detect and identify benign proliferative lesion of the male breast. A biopsy is mandatory in these cases to exclude malignancy. (Foo et al., 2017)

\section{Conclusion}

Ultrasound is the right examination to the benign diagnosis. In the case was shown lesion on retro areola left breast in accordance BI-RADS 4 with lymphadenopathy in the left axilla. Base on the findings results, biopsy results should be used to establish a diagnosis and to make sure benign lesion of the male breast.

\section{Suggestion}

From the above results, a breast ultrasound examination in the case of gynecomastia is recommended to use adequate equipment with Doppler ability, to uphold the diagnosis and to ensure a benign or malignancy by using biopsy action.

\section{Acknowledgements}

We would like to thank the Director of Radiodiagnostic and Radiotherapy Department of Politeknik Kesehatan Kementerian Kesehatan Jakarta II, Ministry of Health for his contributions during the study. We are sincerely grateful to the Directors, Sonographers and staffs of District General Hospital of Cengkareng Jakarta for their valuable contributions, facilities, assistance and constructive suggestions during our study.

\section{Competing Interests Statement}

The authors declare that they have no competing or potential conflicts of interest.

\section{References}

ACR.The American College of Radiologi. (2014). ACR BI-RADS Atlas Fifth Edition. Quick Reference. Retrieved from https://www.acr.org/-/media/ACR/Files/RADS/BI-RADS/ BIRADS-Reference-Card.pdf 
Appelbaum, A. H., Evans, G. F., Levy, K. R., Amirkhan, R. H., \& Schumpert, T. D. (1999). Mammographic appearances of male breast disease. RSNA Radiographics, 19 (3), 559-568. https://doi.org/10.1148/radiographics.19.3.g99ma01559

Berg, W. A., \& Yang, W. T. (2014). Diagnostic Imaging: Breast (2nd ed.). Manitoba: Amirsys

Braunstein, G. D. (2007). Clinical Practice, Gynecomastia. New England Journal of Medicine, 357(12), 1229-1237. https://doi.org/10.1056/NEJMcp070677

Charlot, M., Béatrix, O., Chateaua, F., Dubuissonb, J., Golfier, F., Valettea, P. J., \& Rétya, F. (2013).Breast imaging Pathologies of the male breast. Diagnostic and Interventional Imaging, 94, 26-37. https://doi.org/10.1016/j.diii.2012.10.011

Chen, L., Chantra, P. K., Larsen, L. H., Barton, P., Rohitopakarn, M., Zhu, E. Q., \& Bassett, L. W. (2006) Imaging characteristics of malignant lesions of the male breast. Radiographics, 26, 993-1006. https://doi.org/10.1148/rg.264055116

Chen, P. H., \& Slanetz, P. J. (2014). Incremental clinical value of ultrasound in men with mammographically confirmed gynecomastia. Eur J Radiol., 83, 123-129. https://doi.org/10.1016/j.ejrad.2013.09.021.

Cooper, R. A., Gunter, B. A., \& Ramamurthy, L. (1994). Mammography in men. Radiology, 191, 651-656. https://doi.org/10.1148/radiology.191.3.8037795

Draghi, F., Tarantino, C. C., Madonia, L., \& Ferrozzi, G. (2011).Ultrasonography of the male breast. $J$. Ultrasound., 4(3), 122-129. https://doi.org/10.1016/j.jus.2011.06.004

Foo, E. T., Lee, A. Y., Ray, K. M., Woodard, G. A., Freimanis, R. I., \& Joe, B. N. (2017). Value of diagnostic imaging for the symptomatic male breast: Can we avoid unnecessary biopsies? Clin Imaging, 45, 86-91. https://doi.org/10.1016/j.clinimag.2017.06.004

Johnson, R. E., \&Murad, M. H. (2009). Gynecomastia: Pathophysiology, Evaluation, and Management. Mayo Clin Proc., 84(11), 1010-1015. https://doi.org/10.1016/S0025-6196(11)60671-X

Lemaine, V., Cayci, C., Simmons, P. S., \& Petty, P. (2013). Gynecomastia in Adolescent Males. Semin Plast Surg., 27(1), 56-61. https://doi.org/10.1055/s-0033-1347166

Mathur, R., \& Braunstein, G. D. (1997).Gynecomastia: pathomechanisms and treatment strategies. Hormone Research, 48(3), 95-102. PMID: 11546925. https://doi.org/10.1159/000185497

Mu-oz, C. R., Álvarez, B. M., Mu-oz, G. E., Raya, P. J. L., \& Martínez, P. M. (2010) Mammography and ultrasound in the evaluation of male breast disease. European Radiology, 20(12), 2797-2805. https://doi.org/10.1007/s00330-010-1867-7

Niewoehner, C. B., \& Schorer, A. E. (2008). Gynaecomastia and breast cancer in men. British Medical Journal. 336(7646), 709-713. https://doi.org/10.1136/bmj.39511.493391.BE

Oates, S. D. (2004). Gynecomastia. In: S. E. Singletary, G. L. Robb, \& Hortobagyi, Advanced Therapy of Breast Disease. GN.London : BC Decter Inc.

Rasad, S., \& Ekayuda, I. (2005). Radiologi Diagnostik (2nd.). Jakarta: Faculty of Medicine of Universitas Indonesia.

Stavros, A. T. (2004). Breast Ultrasound. Philadelphia : Lippincott Williams \& Wilkins

Tan, W., DePeri, E., Feigel, D., Perez, E., \&Yasrebi, M. (2016). Use Of Mammograms In Men Is Rising, But Researchers Find Little Reason To Administer. Mayo Clinic. Retrieved from https://www.sciencedaily.com/releases/2006/12/061216104542.htm

\section{Copyrights}

Copyright for this article is retained by the author(s), with first publication rights granted to the journal.

This is an open-access article distributed under the terms and conditions of the Creative Commons Attribution license (http://creativecommons.org/licenses/by/4.0/). 